\title{
Ethnicity in discourse: the interactional negotiation of ethnic boundaries in post-apartheid Namibia
}

\author{
Gerald Stell and Tom Fox
}

To what extent can ethnic boundaries be transcended in interethnic interactions? We are tackling this question in reference to Namibia, a post-apartheid society marked by a legacy of ethnic and racial divisions. Relying on discourse as a source of data, we identify the strategies employed by Namibians in a range of interview data and semi-experimental interethnic interactions for either accentuating or attenuating interethnic boundaries. We identify these strategies at the levels of ethnic categorization, language choice/variation and the management of speaker turns, and place them in the perspective of the participants' perspectives on ethnic Others. Our findings suggest that ethnic categories are salient in our data, although they do not exclude identification with superordinate categories in specific contexts. Our findings also show that patterns of categorization are reflected in language choice and turn management in the interactional context.

Keywords: ethnicity; race; discourse; sociolinguistics; code-switching; Namibia

\section{Introduction}

Essentialist accounts of ethnicity have lost ground following the upsurge of constructionist approaches, which regard ethnicity as both a negotiable boundary and a situational reflection of interactional settings. But the ongoing sociological debate on the relationship between structure and agency in identification processes suggests that, even where ethnicity is situational and negotiable, its potential for dissolving or being subordinated to other social identities is to a large extent constricted by historical patterns of inter-group power relations. To what degree can ethnicity be superseded by other social identities in societal contexts marked by legacies of ethnic segregation?

We are tackling this question against the background of the social changes that have been affecting Namibia, a post-apartheid society where ethnicity is a salient social category historically co-defined by mainly race, language and place of origin. The methodology that we employ involves the study of individual narratives, and of the negotiation of ethnic identity in semi-experimental interactions simultaneously involving members of distinct traditionally established Namibian ethnic groups.

The article is organized as follows. First, we provide a brief overview of literature on ethnic boundaries and of their negotiability against the general social background of Namibia. We then present the notion of ethnicity as a discursive phenomenon in 
general and, more specifically, as a discursive phenomenon observable within interethnic communication. Following a presentation of the data, we go on to identify strategies of identity negotiation based on individually elicited narratives and interethnic interactions. We categorize our findings into strategies of boundary accentuation and boundary attenuation, which we refer to as 'dissociative' and 'associative behaviours' in interactional contexts, before arriving at a general picture of ethnic identification in interethnic interactions in Namibia.

\section{Ethnic boundaries across sociological contexts}

The term 'ethnicity' took hold from the 1970s onwards in academic and popular usage, where it came to compete with the terms 'race' and 'tribe' (Fenton 2003; Lentz 1995). Its most general definition could be that proposed by Fenton $(2003$, 19): 'a common belief in shared descent, ideas of a place, country, kingdom or other form of

state.' Besides the notion of common descent, the popular usage of the term involves notions of shared 'culture', which could be generally defined as a 'shared and negotiated system of meaning' (Lassiter 2006, 41). More detailed definitions of ethnicity typically reflect the tension between primordialist perspectives, which regard it as inherited and immutable, and constructionist perspectives, which regard it as pliable across contexts (Verkuyten 2004). Some recent definitions, however, clearly attempt to overcome this theoretical hiatus. In Jenkins' view, ethnicity (just as social identity at large) is located at the intersection between two mutually reinforcing processes, that is 'internal definitions', by which a given individual envisions his/her own social/ethnic group membership, and 'external definitions', whereby that same individual is categorized by others as belonging to a given social/ethnic group (2003, 60-61). In some respects, Jenkins' definition of ethnicity builds on a Barthian constructionist theoretical legacy, in which ethnicity is regarded as a boundary drawn and negotiated between 'Us' and 'Them' (Barth 1969).

Analyses in terms of social boundaries can not only summarize inter-group relations in general; they can also describe the cultural shape that ethnic identities assume (Lamont and Molnar 2002). In Barth's view, social boundaries do not demarcate fixed cultural repertoires. Rather, they situationally manifest identification with groups via 'diacritic features', whose main function is to signal difference from other groups whenever expressing difference is relevant to the group's interests (Barth 1969). A notable property of these diacritic features is that they may have diverse origins. Importantly, they can also simply be invented. As such, diacritic features may be appealed to in order to accentuate interethnic boundaries, but they may also just as well be kept from rising to the surface in order to attenuate them. A range of sociolinguistic studies undertaken in urban Europe may aptly illustrate the notion of malleable interethnic boundaries. Language varieties, referred to as 'multiethnolects', have arisen in urban Europe as symbols of solidarity among diverse immigrant populations. One among the characteristics of multiethnolects is that they involve elements from diverse heritage languages, or in other words, diacritic features that manifest 'new ethnicities', that is pan-ethnicities straddling established interethnic boundaries (Rampton 1995). 
Despite suggesting that boundaries can be persistent, the Barthian view of ethnicity has drawn criticism for neglecting dimensions of social differentiation that lie beyond the grasp of the agent (Eriksen 2002, 128). Such dimensions of social differentiation are implied in the concept of race, accepted as a subtype of ethnicity despite sometimes being considered to be opposed to it by virtue of its historically coercive character (Jenkins 2003). Phenotypical cues in societies marked by rigid racial projects have been shown to pre-ordain rigid boundaries. In line with Barthian boundaries, racial boundaries can also be signalled by diacritic features, which are either drawn from preexisting cultural repertoires, or invented. An example is the grammatical innovations that have been introduced in African American Vernacular English, seemingly for the purpose of creating distance from European American linguistic usage amid the general context of the historically rigid 'binary' racial project of the USA. ${ }^{1}$ However, unlike Barthian boundaries, racial boundaries inevitably interrelate with social stereotypes that are activated before diacritic features signalling 'Us' and 'Them' even manifest themselves. Pressure to conform to such stereotypes may constrict the negotiability of racial boundaries, as is aptly summarized by an African American's comment recorded by Rickford $(1999,275)$ : 'Once they catch you talkin' white, they never let it go.' In summary: even though the salience of racial boundaries is to some extent negotiable, and should as such be studied in terms of diacritic features, much of it remains best understood as a function of pre-existing racial stereotypes.

Namibia - administered by South Africa until 1990 - is a post-apartheid society that displays the legacy of a 'ternary racial project' revolving around a threefold distinction between the racial categories 'black', 'coloured' and 'white', each of which was allocated specific socio-economic positions. These racial categories were superimposed on strongly stereotyped ethnic distinctions (Pendleton 1996) grounded in among other things language, and, especially in the case of blacks, in ethnic 'homelands' or ethnic neighbourhoods in urban areas. In these terms, apartheid policy was designed to undermine any potential for integration between racial groups, but also - except in the case of whites - within racial groups. Independence (1990) put an end to apartheid and thus shaped a new context for interethnic relations. One defining element of that new context was the abolition of influx control, resulting in the increasing urbanization of black populations, enlarging their scope for mutually interacting, and for interacting with the country's other population groups (Pendleton 1996). Another defining element was the emergence of a new discourse of racial relations with attributes strongly reminiscent of South Africa's 'two-nations dis-course. ${ }^{2}$ That discourse seems to underlie Namibian affirmative, where 'whites' are opposed to a 'black' category encompassing all non-whites action schemes, which distinguish between a 'racially advantaged' category and a 'racially disadvantaged' category (van Rooyen 2000, 24). What impact do Namibia's old and new contexts of interethnic relations have on the salience of Namibian ethnic categories versus other social categories, such as, for example, emergent 'new ethnicities'? To what degree do these Namibian ethnic categories have a bearing on communicative interactions? These are the specific questions that we want to tackle. 


\section{Ethnic boundaries in discourse}

Ethnicity has been studied from different perspectives. The ethnographic approach has traditionally focused on cultural inventories, regarded as the essence of ethnicity. What is called the 'discursive turn' inaugurated a new approach in which language (and its context) is seen as the main conduit for the expression of social identities in general, and of ethnicity in particular (Zienkowski 2011, 3; Drew 1998). As such, discourse reflects as much as enacts social boundaries, which can be described based on various cues observable at different levels of language use. Due to their diverse character, these cues have formed the object of studies undertaken within various theoretical paradigms, which are typically compartmentalized into, among other things, social psychology, discourse analysis or sociolinguistics. Our first task in our study is to identify a theoretical framework broad enough to accommodate a multidisciplinary perspective on the manifestation of interethnic boundaries in discourse.

Following the point of view that a substantial part of social identity is a relational construct (Whetherell 2010, $11-12$ ), we argue that interactions between incumbents of distinct ethnic categories provide a privileged vantage point for observing ethnic boundaries in discourse. A theoretical framework that makes provision for the study of ethnicity at various levels of interactional discourse is the Contextual Theory of Interethnic Communication (CTIC, Kim 2005). Grounded in social psychology while allowing scope for multidisciplinary perspectives, this framework focuses on ethnicity as a mainly linguistic/paralinguistic behaviour, which it categorizes into 'associative' and 'dissociative behaviours', that is behaviours relevant to attenuating and accentuating interethnic boundaries, respectively. The distinction between associative and dissociative behaviours is made on the ground of whether individuating and consonant behaviours supersede their opposites, that is categorical and dissonant behaviours, or vice versa. Individuation and categorization - notions borrowed from Tajfel (1978) - form the two opposite ends of a continuum of behaviours. Individuation takes place in reaction to information about the Other's individual attributes, whereas categorization takes place in reaction to information about that Other's ethnic category membership.

Dissociative behaviours manifest interactants' strategies for implementing and endorsing ethnic categorization, whereas associative behaviours manifest their strategies for avoiding or resisting ethnic categorization in the interest of creating individuation potential (see Kim 2005: 310-311, see further Stokoe 2012). When interactants categorize one another in terms of ethnic category membership, they do so in relation to stereotypical views of ethnic Others (Operario and Fiske 2001, 31 -35; Oakes 2001, 9). It is therefore important to identify ethnic stereotypes relevant to the participants, especially when they possess a racial dimension (cf. Section 1). More specifically, it is appropriate to elicit ethnic stereotypes through researcher-led interviews, anticipating the probability that they may not find expression in any given naturalistic interethnic interaction. Ethnic stereotypes identified in interview data then become a framework of reference while searching for associative/dissociative behaviours in interethnic interactions. 
Other cues of associative/dissociative behaviours assume the form of what Kim unspecifically calls 'convergence' and 'divergence'. These two concepts have been elaborated on in detail by Communication Accommodation Theory (CAT, cf. Gallois et al. 2005). According to CAT, convergence and divergence can be observed at the level of discourse management (i.e. topic selection, face maintenance, back channelling, turn management). They can also be observed at the level of language variation. When interactant $A$ and interactant $B$ are linguistically converging with one another, CAT assumes that they are displaying an associative behaviour. When interactant $\mathrm{A}$ is linguistically diverging from interactant $\mathrm{B}$, or at least not converging with him/her, CAT assumes that A is displaying a dissociative behaviour.

The general source of data that we wish to draw on for the purpose of studying the negotiation of ethnic boundaries is discourse in a broad sense, more specifically discourse in the context of interethnic interactions. The general theoretical framework that we are adopting for analysing interactional data is CTIC, through which different levels of discourse can be simultaneously searched for strategies of boundary attenuation/accentuation. Anticipating the impact of ethnic stereotypes on interactional discourse, and to reduce our dependence on naturalistic data for identifying them, we first attempt to characterize interethnic boundaries on the basis of interview data on ethnic stereotypes. In the next section we present the data and the methodology that we employed for collecting them.

\section{Data collection and data description}

The experimental arrangement that we chose for staging interethnic interactions is akin to that implemented by Bell (2001) for the purpose of his sociolinguistic research on inter-group language variation. Concerned with communication between two socially contrasting groups - Maori and Pakeha (i.e. white New Zealanders) -Bell systematically compared their respective in-group and out-group language behaviours by observing them in both in-group and out-group communication settings. For the purpose of this research, we recruited self-declared members of various Namibian ethnic groups and placed them in interaction with one another within in-group settings, as well as within out-group settings involving members of another ethnic group, obtaining as a result a wide range of ethnic combinations. For the purpose of anticipating interethnic boundaries at interactional level, we interviewed every participant prior to the interaction in order to identify ethnic categories relevant to them (cf. Section 2).

The participants recruited for this research were all students from the Windhoek campus of the University of Namibia, between nineteen and twenty-four years of age, with roughly equal numbers of male and female participants. Following the preliminary interviews, they were split into distinct and widely identifiable ethnic groups, namely, Afrikaners, Coloureds, Hereros, Ovambos, Namas and Damaras. Some of these groups share an in-group language: the Afrikaner and Coloured participants were first language (L1) Afrikaans-speakers; the Nama and Damara participants were L1 Khoekhoegowab-speakers; and the Hereros and Ovambos were L1 Otjiherero- and Oshiwambo-speakers. All participants indicated being fluent in Afrikaans, except for the Ovambo participants, who came from the northern districts. ${ }^{3}$ 
The ethnic groups involved in this research represent the three racial categories enforced during the apartheid era: white (represented by the Afrikaners), coloured (represented by the Coloureds and the Namas ${ }^{4}$ ) and black (represented by the Ovambos, Hereros and Damaras).

While the participants were generally well acquainted with their ethnic peers, they rarely knew their peers from other ethnic groups. The study was presented to them as an experiment on communication patterns with no overt reference to ethnicity. No instructions were issued to the participants regarding topics to be discussed, and the interactions were recorded without the researcher being present, so as to reduce the observer's paradox. The resulting corpus of interactions comprises thirty-six filmed interactions (six in-group interactions and thirty out-group interactions) of between one hour and one and a half hours each, which were all transcribed and transliterated by ingroup members with relevant linguistic knowledge. The number of words transcribed for each interaction averages between 6,000 and 7,000.

The preliminary interviews were organized around general themes, namely personal histories, ethnicity, language, and identification with Namibian racial labels and Namibian nationhood. Personal histories were elicited through questions on, among other things, geographic origin, experience of interacting with other ethnic groups, and the ethnic composition of friendship circles. Comments on ethnicity were elicited by means of questions on perceptions of and orientations to ethnic Others, such as for example: 'If I say "Ovambo", what images does it evoke in you?', o $r$ 'Which ethnic group do you prefer to hang out with/do you avoid hanging out with?' A systematic comparison between interviews - following the principles of Constructivist Grounded Theory (Charmaz 2006) - allowed for new questions designed to prompt reactions to comments made by previously interviewed participants, such as for example: 'The Ovambo girl I interviewed just now said that Herero people are arrogant. Do you agree with that statement?' Language-related questions (e.g. 'What language do you generally prefer to speak? With whom?') were phrased such as to relate ethnicities to specific language attributes. By contrast, questions on Namibian nationhood (e.g. 'Do you feel Namibian before being Ovambo or the other way around?') were phrased such as to give scope for ethnically neutral identities to manifest themselves.

The analysis of the data proceeds as follows. First, a general overview is given of ethnic self-categorizing and ethnic categorizing of Others in the interview data. In the process, specific attention is also given to ethnically neutral social categories that the participants evoke. In the next stage, the focus shifts towards interactional data. These data are analysed from the perspective of ethnic categorization (i.e. the use of ethnic labels or generalizing statements on the ethnic Other), which offers insights into the most overt strategies of boundary negotiation. They are also analysed from the perspective of language variation (i.e. patterns of language choice within the interaction) and turn management, in which covert strategies of boundary negotiation can be identified, while being quantifiable in some respects. The types of boundary negotiation identified in the process are subdivided into associative and dissociative behaviours, before being placed in the contextual perspective of Namibia's general landscape of interethnic relations. 


\section{Interview data: the participants' discourses on ethnic categories}

In order to identify the contents of ethnic categories relevant to them, the participants were first prompted for stereotypical characterizations of the main Namibian ethnic groups. Most stereotypical characterizations were based on prototypes, that is involving stereotypes referring to 'average' members of the ethnic group under discussion (cf. Operario and Fiske 2001, 28). These stereotypical characterizations can be ordered around a range of themes. One of these themes is that of social insulation. Some ethnic groups are said not to mix, such as, in particular, whites, Hereros and Coloureds. Ethnic pride also proves a recurrent theme. Hereros 'don't like to diverge from their own culture', Coloureds 'think they are the best of both worlds' (i.e. white and black), or 'above us Damaras' (Damara 1,2). Namas 'think they are superior (to Damaras), [because] they think we stole their language' (Damara 2). Whites 'think they know better' (Nama 1) and are widely accused of being 'racist'. Language behaviours - often associated with ethnic pride - are discussed: whites 'get offended when addressed in English' (rather than in Afrikaans), while Hereros 'address you in Herero even when they know you don't s peakit'. Next among the main themes comes rudeness. Whites show a predisposition for rudeness by being 'impatient'; Coloureds, Namas and Damaras show a predisposition for rudeness through their fondness of swearing. The theme of traditional mores is broached by Hereros and Ovambos in relation to each other (e.g. Hereros are 'cow-eaters', Ovambos are 'chicken-eaters'). The theme of what could be termed 'blandness' is broached by many non-white informants in relation to whites: They 'don't express themselves much', their music is 'dull' and 'slow'.

Characterizing ethnic Others is sometimes accompanied by self-categorizing as 'Us' versus 'Them', which is often articulated along positive stereotypes applied to the ingroup. Herero 2 says of Coloureds that 'they have their own way of seeing things', opposed to the Herero way in which 'we respect our elders'. Damara 1 says of Coloureds that 'they look forward', as opposed to 'Us Damaras', who 'look backward to help those who helped us'. Regarding whites, Coloured 3 says that 'they like to sit around and drink', whereas 'we (Coloureds) are more lively, we dance'. O n some occasions, self-categorization endorses stereotypes applied by Others: all Herero informants agreed on characterizing stereotypical members of their own ethnic group as 'proud'.

Whereas the above described stereotypes starkly profile 'Us' against 'Them', categorizing ethnic Others occasionally leads ethnic boundaries to be downplayed, specifically between Namas and Damaras, and between Coloureds and whites, where linguistic commonalities are stressed. In the case of Coloureds and whites, however, whites are those who tend not to perceive a linguistic boundary, while Coloureds do. Musical tastes are also described as bonding factors. Namas and Coloureds, for example, are said 'to listen to the same music' (Nama 1), while Herero 3 emphasizes his taste for Ovambo music. When it occurs in the data, exemplar-based stereotyping (i.e. stereotyping of subtypes within the ethnic group, cf. Operario and Fiske 2001, 28) could also amount to boundary attenuation, since it has less of a generalizing value than prototype-based stereotyping. For example, some informants concede that 
'some' whites are 'nice', or that Germans behave better than white Afrikaansspeakers.

Narrating specific negative out-group experiences is the main strategy of boundary accentuation in the interview data. Experiences of white racism - implicit or explicit are frequently narrated by members of non-white groups, while experiences of black racism are also narrated by the Coloured and white participants. Aiming to achieve a general perspective on out-group experiences, we complemented the elicitation of these experiences with questions to the participants on the composition of their social networks. Coloureds described theirs as multi-ethnic, and multi-ethnic to the point of including whites. The Nama and Damara participants also claimed to have multiethnic social networks, albeit not multi-ethnic to the point of including whites, and one white informant described herself as 'used to mingling with other groups'. By contrast, the Herero and Ovambo informants described their social networks as homogeneously Herero and Ovambo, respectively, even though it transpired that they do socialize with other black groups.

Insights into the rigidity of ethnic boundaries could be gained through the question: 'With which ethnic group would you rather associate if none of your ethnic peers were present?' Answers to that question did not always reflect the stereotypical representations of ethnic Others previously elicited from the participants, or the descriptions that they had given of their social networks. Only one Coloured informant stated a preference for associating with whites, while the other three stated feeling discomfort when being among whites. Namas stated a preference for associating with Damaras, while Damaras stated a preference for associating with other black groups, as did the Hereros and Ovambos. Among the latter, one was particularly vocal about not wanting to associate with Coloureds. Whites remained evasive - as were many other informants - in naming no preferred ethnic group outside of their own.

Finally, the participants were asked to what extent they identify with Namibian nationhood rather than with their traditional ethnic identity. Intended to discover symptoms of pan-ethnic superordinate identities, this question triggered mixed answers. Those identifying most with Namibian nationhood turned out to be Ovambos and whites. Those identifying least with it were Hereros, one of whom even dismissed the term 'Namibian' as referring to a 'mixed race' background. The other groups occupy an intermediate position, in that they foregrounded their traditional ethnic identity while hyphenating it with Namibian-ness. Interestingly, most non-white informants - except for two Coloured informants - self-applied the adjective 'black' without specifying it, suggesting that 'blackness' may have a panethnic value. The white informants identified as 'Afrikaans' rather than 'white'.

The participants' discourses on ethnic Others suggest at first sight that ethnic boundaries are salient in Namibian society. They seem to be most rigid between whites and non-whites, and, to a lesser extent, between Coloureds and blacks. The participants' discourses may reveal positive perceptions of ethnic Others within racial categories (e.g. 'black'), or between linguistic categories (e.g. 'Afrikaans'), but these positive perceptions are often unilateral. However, there seem to be mutually shared positive perceptions, accompanied by occasional manifestations of a black pan-ethnic identity among blacks and, to a lesser extent, Coloured participants. In the next 
sections we examine to what extent the discourses on ethnic Others described in this section are reflected in interethnic interactions.

\section{Dissociative and associative behaviours in interethnic interactions}

Dissociative behaviours accentuating interethnic boundaries manifest themselves most overtly in the interactional data through ethnic categorizing or through participants endorsing ethnic categories applied to them. Associative behaviours attenuating interethnic boundaries manifest themselves most overtly through the creation of scope for individuation, the stressing of commonalities between interacting ethnic groups, or identification with superordinate identities. Both dissociative and associative behaviours manifest themselves more covertly through patterns of language choice or turn management.

\subsection{Dissociative behaviours}

Ethnic categorizing in the interactions can take place overtly (i.e. through ethnic labels referring to the out-group or to the in-group). Ethnic labelling assumes the form of deictic Us/Them polarization, that is the reification of participants' ethnicities through using the pronouns 'we/you' (cf. van Dijk 1993, 109), as in 'I heard about you Hereros' (Nama-Herero interaction). In-group ethnic labelling can be illustrated by a Coloured participant endorsing the swearing stereotype applied by Others to Coloureds (cf. Section 4) in her answer to a question that she was asked by her Nama interlocutor about her propensity to swear: 'You know how we Coloureds are!'

Ethnic categorizing more often takes place covertly (i.e. via implicatures suggesting correlations between given stereotypical category attributes and assumed ethnic category memberships). When asking his Coloured interlocutors whether they live in Khomasdal, Nama 2 shows that he is categorizing his interlocutors as Coloured (even though no explicit ethnic self-categorization had taken place by that stage) since Khomasdal is Windhoek's historical Coloured neighbourhood. In the Damara-white interaction, White 2 asks her Damara interlocutors where they live. On hearing 'Damara 7' (i.e. the historical Damara neighbourhood in Windhoek), White 2 marks a hesitant pause. Damara 2 cuts that pause short by asking ironically: 'Maybe never heard of Katutura?' Since Katutura is the neighbourhood where most of Windhoek's non-white population resides, and that its existence can as such not possibly have escaped any Windhoek resident, the question's underlying premise is that its addressee is an incumbent of the white category, endowed with its stereotypical propensity for social insulation from non-whites. Overall, the question's effect on the interaction is to make salient the social distinction between non-white and white.

Whereas covert ethnic categorizing as exemplified above sometimes meets with disapproval by the targets (cf. Section 5.2), it occasionally also meets with unconditional endorsement, whereby ethnic boundaries are acknowledged. In Extract (1), Herero 1 first asks Ovambo 1 to confirm or disconfirm eating dog meat as an attribute of the Ovambo ethnic prototype, before subsequently asking her - upon her positive answer - whether she individually conforms to the Ovambo ethnic prototype. 
On again answering in the affirmative, Ovambo 1 locally confirms the existence of an ethnic boundary between herself and her Herero interlocutors.

(1)

Herero 1:

Oh I heard that the Ndongas they kamma [allegedly] eat dog meat, kamma [like] it's a delicacy?

Ovambo 1:

Ja I think all the tribes in the North eat dog meat.

Herero 1:

So you also do?

Ovambo 1:

Ja.

On occasions, endorsing ethnic prototypes disrupts emerging associative behaviours. In the Herero-Ovambo interaction (featuring two Ovambo female participants and two Herero male participants), the Herero participants probe their Ovambo interlocutors for their stances on dating members of other ethnic groups, which turn out to be positive. When Herero 2 is asked by his Ovambo interlocutors a question similar to that which he asked them in the first place, he first gives an unconditionally positive answer. Ovambo 1 - mindful of the Herero stereotype of social insulation (cf. Section 4) - shows signs of doubting the sincerity of that answer. Acknowledging the representativeness of that stereotype while maintaining openness to interethnic dating, Herero 2 finds himself prompted to rephrase his answer as a conditionally positive one, that is subject to the principle that marriage outside of the Herero group is not acceptable (cf. Extract (2)). Herero 2 thereby accentuates the ethnic boundary between himself and his Ovambo interlocutors.

(2)

Ovambo 1:

What about you guys? Do you mind dating other tribes?

Herero 2:

I don't.

Ovambo 1:

You don't?

Herero 1:

I don't mind, but I know for a fact that I have to marry a Herero woman once I'm ready to marry.

Diverging language choices, of which occurrences are found in the data, can be interpreted as a dissociative behaviour accentuating interethnic boundaries (cf. Section 2). In Extract (3), Coloured 2 interrupts a mostly Afrikaans exchange taking place between the two white participants by taking the floor in English (which can be seen as divergence on his part). His departure from the interaction's default language could be a bid to claim authority without conforming to white linguistic norms, thus accentuating the ethnic boundary between himself and the white participants. 
(3)

White 2:

Weet jy wat is dit dit is (.) die lecturers kyk na hoe die persoon optree en wat hy (.) en wat hy in sy mind $(\ldots)=$

[You know what is this (.) this is the lecturers look at how the person behaves and what

he [has got] on his mind.]

Coloured 2:

=hoe hy sou dit uitbeel $=$

[How he would represent it.]

White 1:

$=$ hoe interpretate hy

[How he interprets.]

Coloured 2:

And how do they judge you?

White 1:

Nee maar dit is net die begin van die interviews

[No but it's just the beginning of the interviews]

The potential for dissociative behaviours can be tentatively quantified by measuring the use of languages across interethnic interactions (cf. Table 1). The fact that whites and Coloureds maintain Afrikaans as a medium of interaction instead of using the language of their interlocutors suggests a low potential for associative behaviours. Potentials for dissociative behaviours can also be quantified by summarizing frequencies of turn-taking for each ethnic group across interethnic interactions (cf. Table 2). Uneven frequencies across interacting ethnic groups can indicate perceived inequality between them, and thus awareness of ethnic boundaries.

Table 2 shows that the distribution of turns is generally skewed in favour of whites in interethnic interactions where they are involved. This suggests that the white participants tend to be in a position of power within the interactions, possibly causing awareness of ethnic boundaries, and reflecting at an interactional level Namibia's white/non-white dichotomy (cf. Section 1).

\subsection{Associative behaviours}

Participants occasionally distance themselves from the ethnic stereotypes attributed to them, thus creating scope for individuation. Self-distantiation from stereotypical ethnic attributes may be achieved through explicitly denying the validity of ethnic stereotypes. An example of this strategy is found in the Damara-White interaction, where the topic of music is broached. In Extract (4), Damara 2 seems to posit a correlation between whites and rock music. The reaction of White 2 is to cast doubt on the legitimacy of that correlation. Damara 2 becomes aware of being caught in the act of ethnic categorizing and apologetically goes on to ask White 2 whether she listens to house music, her favourite musical genre (associated with black Africans in general). By answering in the affirmative, White 2 suggests potential common ground between herself and her Damara interlocutors, thus reducing the salience of the white-Damara ethnic boundary. 
(4)

\section{Damara 2:}

Like he asks if you go to a white club with Rock and Roll, would you enjoy and depends on who you are with.

White 2:

Wie sê vir jou witmense hou van Rock and Roll?

[Who told you white people like Rock and Roll?]

Damara 2:

((laughs)) I was gonna ask that, I was gonna ask that. Do you guys listen to House?

White 2:

Ja I listen to it.

Shared ethnic attributes are occasionally emphasized, such as hair texture and haircare habits, which are often discussed among black female participants. Other comparable associative behaviours can be identified whereby interactants emphasize experiences of mobility across the ethnic boundary between themselves and their interlocutors. Although no ethnic categorizing had taken place by that stage, one of the Damara participants emphatically shares with her Coloured interlocutors that she previously lived in Khomasdal (a neighbourhood associated with Coloureds). Similarly, a male Nama participant signals to his female Coloured interlocutor that he dated a few 'Coloureds'.

Associative behaviours occasionally manifest themselves through categorizing self and/or interlocutors as incumbents of pan-ethnic superordinate identities. One such identity involves 'blackness', which surfaces in the Herero-Ovambo interaction, at a juncture where traditional beliefs are discussed (Extract (5)). The 'black' category manifests itself further in the form of self-disparaging exclamations such as 'ag these blacks...' (Ovambo 2), or evaluative comments such as 'blacks have funny stuff' (Herero 2). In the Damara-Ovambo interaction, an Ovambo participant asks her Damara interlocutor whether her surname ('Jager', a typical Afrikaans surname) is 'a black surname'.

(5)

Ovambo 2:

To blacks, people don't die natural deaths. It always has to be witchcraft.

Herero 1:

Seriously kau [I'm telling you], everything in blacks is just witchcraft.

Namibian-ness as a superordinate category also emerges. That category indirectly arises in the White-Herero interaction as a strategy for bridging the black/white boundary in the exchange. White 1 introduces a distinction between an inclusive multi-ethnic 'Us' and a 'Them' embodied by 'foreigners': 'These foreigners come here and grab our places at educational institutions.' Namibian-ness also surfaces in the Herero-Damara interaction. Before being labelled a 'die-hard Namibian' by his Damara interlocutor, one of the Herero participants declares: 'Even if I had to become prosperous, I would never want to be in a position (.) it never has to be against my country.' 
Table 1. Use of languages across interactions (\%).

\begin{tabular}{|c|c|c|c|c|c|c|}
\hline Language group & Ovambos & Hereros & Damaras & Namas & Coloureds & Whites \\
\hline \multirow{3}{*}{$\begin{array}{l}\text { Ovambos } \\
\text { interacting } \\
\text { with }\end{array}$} & E: 64.2 & E: 99.6 & E: 99.5 & E: 99.6 & E: 99.7 & \multirow[t]{3}{*}{ E: 100} \\
\hline & A: 0.4 & A: 0.4 & A: 0.5 & A: 0.4 & A: 0.3 & \\
\hline & I: 35.4 & & & & & \\
\hline \multirow{2}{*}{$\begin{array}{l}\text { Hereros } \\
\text { interacting } \\
\text { with }\end{array}$} & E: 99.5 & E: 13 & E: 94.1 & E: 9.4 & E: 7.2 & E: 33.4 \\
\hline & A: 0.5 & $\begin{array}{l}\text { A: } 6.7 \\
\text { I: } 80.3\end{array}$ & A: 5.8 & $\begin{array}{l}\text { A: } 85.5 \\
\text { I: } 5.1\end{array}$ & A: 91.6 & $\begin{array}{l}\text { A: } 66.4 \\
\text { I: } 0.2\end{array}$ \\
\hline \multirow{2}{*}{$\begin{array}{l}\text { Damaras } \\
\text { interacting } \\
\text { with }\end{array}$} & E: 99.4 & E: 93 & E: 13 & E: 3.7 & E: 15.3 & E: 13.2 \\
\hline & A: 0.6 & A: 7 & $\begin{array}{l}\text { A: } 4 \\
\text { I: } 83\end{array}$ & $\begin{array}{l}\text { A: } 5.3 \\
\text { I: } 91\end{array}$ & A: 84.7 & A: 86.7 \\
\hline \multirow{3}{*}{$\begin{array}{l}\text { Namas } \\
\text { interacting } \\
\text { with }\end{array}$} & E: 99.6 & E: 5.4 & E: 1.8 & E: 0.5 & E: 2.4 & E: 2 \\
\hline & A: 0.4 & A: 86.4 & A: 3.1 & A: 1.2 & A: 97.1 & A: 98 \\
\hline & & I: 6 & I: 95.1 & I: 98.2 & I: 0.5 & \\
\hline \multirow{2}{*}{$\begin{array}{l}\text { Coloureds } \\
\text { interacting } \\
\text { with }\end{array}$} & E: 99.5 & E: 15.7 & E: 16.8 & E: 2 & E: 36 & E: 20.2 \\
\hline & A: 0.5 & A: 83.3 & A: 83.2 & A: 98 & A: 64 & A: 79.8 \\
\hline \multirow{2}{*}{$\begin{array}{l}\text { Whites } \\
\text { interacting } \\
\text { with }\end{array}$} & E: 100 & E: 24 & $\mathrm{E}: 5$ & E: 3.1 & E: 5.8 & $\mathrm{E}: 3$ \\
\hline & & A: 76 & A: 95 & A: 96.9 & A: 94.2 & A: 97 \\
\hline
\end{tabular}

Note: A: Afrikaans, E: English, I: In-group language. Percentage of lexemes from each language in the speech of members of the ethnic groups named in the left column in interaction with members of the ethnic groups named in the top row. For the purpose of establishing linguistic convergence/divergence, the informants were first requested to interact in in-group settings to provide a general reference for establishing accommodation strategies in out-group settings.

The potential for associative behaviours manifests itself through quantifiable converging patterns of language choice (cf. Table 1, see further Section 5.1).

A comparison between the frequencies of lexemes from Afrikaans, English and indigenous languages across interactions suggests unilateral convergence in interactions involving L1 and L2 Afrikaans-speakers. The Nama, Damara and Herero participants use mostly Afrikaans to accommodate their white and Coloured interlocutors, in reflection of what CAT calls 'upward convergence' with social groups historically perceived as ranking higher in society (Giles 1979, see further Section 1). By contrast, communication between participants who do not have Afrikaans as an L1 shows - except in the case of the Namas and Damaras - mutual convergence (i.e. away from the respective in-group languages) via mostly Afrikaans or English. Whereas both unilateral and mutual convergence can be read as associative behaviours, their respective distribution testifies to a dichotomy between whites/Coloureds and blacks in interethnic communication patterns, reflecting societal divisions enforced during the apartheid (cf. Section 1).

Mutual convergence can also take place via in-group languages. An example is found in the Nama-Herero interaction, where the participants intersperse their speech with features from their interlocutors' in-group languages, as illustrated by Extract (6), where Nama 1 uses the Otjiherero response marker ayee ('no') for joking purposes, thus 'crossing' into Herero ethnicity (Rampton 1995). Whereas such instances of crossing seem to cause amusement among black interlocutors, they seem 
Table 2. Distribution of turns across interethnic interactions (\%).

\begin{tabular}{lcccccc}
\hline Language group & Ovambos & Hereros & Damaras & Namas & Coloureds & Whites \\
\hline $\begin{array}{l}\text { Ovambos } \\
\text { interacting with }\end{array}$ & 100 & 53.6 & 51.6 & 53.3 & 46.8 & 38.4 \\
$\begin{array}{c}\text { Hereros } \\
\text { interacting with }\end{array}$ & 46.4 & 100 & 43.2 & 45 & $\begin{array}{c}\text { One participant } \\
\text { missing }\end{array}$ & 30.5 \\
$\begin{array}{c}\text { Damaras } \\
\text { interacting with }\end{array}$ & 48.4 & 56.8 & 100 & 47.4 & 52 & 47.5 \\
$\begin{array}{c}\text { Namas } \\
\quad \text { interacting with }\end{array}$ & 46.7 & 55 & 52.6 & 100 & 58.5 & 25.3 \\
$\begin{array}{c}\text { Coloureds } \\
\text { interacting with } \\
\text { Whites } \\
\text { interacting with }\end{array}$ & 53.2 & $\begin{array}{c}\text { One participant } \\
\text { missing } \\
69.5\end{array}$ & 48 & 41.5 & 100 & 44 \\
\hline
\end{tabular}

Note: Percentage of turns taken by members of the ethnic groups named in the left column in interaction with members of the ethnic groups named in the top row.

unwelcome when initiated by whites. An illustration is found in the Coloured-White interaction, where a white participant greets her Coloured interlocutor using a Coloured Afrikaans feature - the post-alveolar affricate $\left[\mathrm{d}_{3}\right]$ in the second person pronoun jy ('you') in the question is dit jy? ('is this you?') (Ponelis 1998, 15). Coming from a member of a perceived high-status group, this instance of convergence is referred to as 'downward convergence' in CAT (Giles 1979). Probably as a result of the negative connotations of that type of convergence, the white participant's linguistic move does not spur the Coloured participants to deploy Coloured Afrikaans features in return.

(6)

Nama 1:

Frank jong, daai man slaap baie. Hy slaap baie.

[Frank man, that guy sleeps a lot. He sleeps a lot.]

Herero 1:

Jy slaap ook baie.

[You sleep a lot too.]

Nama 1:

Ayee nee man ernstig kau Frank is erg.

[No man, seriously, Frank is bad, I'm telling you.]

Besides instances of mutual convergence through in-group languages, a qualitative perspective on language use reveals that mutual convergence also takes place via isolated linguistic features seemingly invested with the value of a non-white superordinate identity. These linguistic features - seldom or never used by whites involve a range of discourse markers of Khoi-San origin (generally acknowledged in Afrikaans lexicographic sources) or of indeterminate origin such as the interrogative particle nè ('isnt it?'), the ironic dubitative marker kamma ('allegedly', 'like'), the 
interrogative or exclamative markers hoeka and etse/aitsa, the indicator of shared knowledge kau ('I'm telling you'), and the polysemic word $n l l a$ ('good, nice').

Finally, patterns of turn-taking across interethnic interactions (cf. Table 2) are more evenly, or close to evenly, distributed across ethnic groups within interactions involving non-whites. These patterns could suggest a sense of equality among the non-white interactants, hence potential for boundary attenuation between them. The validity of this interpretation seems to be confirmed by the instances of explicit identification with superordinate 'black' identities or by language behaviours in interethnic interactions between the non-white participants.

\section{Summary and conclusion}

Ethnic stereotypes are salient to the participants involved in the study, and suggest that interethnic boundaries are still rigid in modern-day Namibian society. In general, the interview data suggest that the participants value the maintenance of ethnic boundaries, despite occasional displays of openness to crossing or transcending them. The interactional data show that ethnic categorizing often takes place covertly through dissociative behaviours that make interethnic boundaries salient.

However, the interactional data revealed that interethnic boundaries are strategically negotiated through specific associative behaviours. The participants occasionally resist ethnic categorization, or categorize self and/or interlocutors as incumbents of pan-ethnic superordinate identities. One such pan-ethnic identity revolves around a sense of 'blackness'. Reflected in non-white interactions in mutually converging language choices and in the even distribution of turns across ethnic groups, the most obvious linguistic manifestation of that pan-ethnic identity is the use of specific lexical items rarely or never used by or with whites.

This study shows that interethnic interactions in Namibia reflect at various levels the post-apartheid 'two-nations discourse', although certain views held by the Coloureds and some of their linguistic behaviours suggest that the legacy of the apartheid ternary racial project is still salient. At a methodological level, this study suggests that research on identity negotiation is well served by semi-experimental interactional data: the qualitative findings that such data yield can be supported by quantitative summaries of patterns of language choice and turn management, through which generalizations and comparisons across distinct societal settings are facilitated.

\section{Funding}

This work was supported by a research grant awarded in 2012 to the authors by the French Institute of South Africa.

\section{Notes}

1. Habitual 'be' as in 'he be studyin all the time' ('he studies/is studying all the time') provides one illustration. That feature is mostly found among younger AAVE speakers, while it is virtually absent in the usage of the oldest AAVE speakers (Rickford 1999, 263-266). 
2. The notion of a 'two-nations discourse is inspired from a public address delivered by South Africa's former president Thabo Mbeki, which breaks with the 'rainbowist' non-racialist edge of the Mandela years (McDonald 2006).

3. The far northern districts constitute what was known as 'Owamboland' under the apartheid regime. That was the region where Afrikaans was least represented as an L1 or L2 in the years preceding independence (Fourie 1991).

4. There was a distinction between 'coloured' as a racial label - which we use here with a lower case ' $c$ ' - and 'Coloured' as an ethnic label - which we use here with a capital ' $C$ '. Namas were classified as 'coloureds' under the apartheid regime (Robins 2008, 67).

\section{References}

Barth, Frederik. 1969. "Introduction.” In Ethnic Groups and Boundaries. The Social Organization of Culture Difference, edited by Frederik Barth, 9-38. Oslo: Universitetsforlaget. Bell,

Allan. 2001. “'Back in Style': Reworking Audience Design.” In Style and Sociolinguistic Variation, edited by Penelope Eckert and John Rickford, 139-169. Cambridge: Cambridge University Press.

Charmaz, Kathy. 2006. Constructing Grounded Theory. London: Sage.

Drew, Julie. 1998. "Cultural Composition: Stuart Hall on Ethnicity and the Discursive

Tufalc 18 (2): 171-196.

Eriksen, Thomas Hylland. 2002. Ethnicity and Nationalism. Anthropological perspectives. London: Pluto.

Fenton, Steve. 2003. Ethnicity. Cambridge: Polity Press.

Fourie, David. 1991. "Sociolinguistic Trends in Owamboland." News from the Languages Society of Namibia 2 (2): 6.

Gallois, Cindy, Tania Ogay, and Howard Giles. 2005. "Communication

AcEbeomodatibnok Back and a Look Ahead." In Theorizing about Intercultural Communication, edited by William B. Gudykunst, 121-148. London: Sage.

Giles, Howard. 1979. "Ethnicity Markers in Speech." In Social Markers in Speech, edited by Klaus R. Scherer and Howard Giles, 251-290. Cambridge: Cambridge University Press.

Jenkins, Richard. 2003. "Rethinking Ethnicity: Identity, Categorization, and Power." In Race and Ethnicity: Comparative and Theoretical Approaches, edited by John Stone and Rutledge Dennis, 59-71. London: Blackwell.

Kim, Young Yun. 2005. "Association and Dissociation. A Contextual Theory of Inter-

ethnommunication." In Theorizing About Intercultural Communication, edited by William B. Gudykunst, 323-349. Thousand Oaks, CA: Sage.

Lamont, Michèle and Virág Molnar. 2002. "The Study of Boundaries in the Social Sciences." Annual Review of Sociology 28: 167-195. doi:10.1146/annurev.soc.28.110601.141107.

Lassiter, Luke E. 2006. Invitation to Anthropology. 2nd ed. Lanham, MD: Altamira Press.

Lentz, Carola. 1995. "“Tribalism' and Ethnicity in Africa. A Review of Four Decades of Anglophone Research." Cahiers de Sciences Humaines 31 (2): 303-308.

McDonald, Michael. 2006. Why Race Matters in South Africa. Scottsville: University of Kwazulu-Natal Press.

Oakes, Penelope. 2001. "The Root of all Evil in Intergroup Relations? Unearthing the Categorization Process." In Intergroup Processes, edited by Rupert Brown and Samuel L. Gaertner, 3-21. Malden, MA: Blackwell.

Operario, Don, and Susan T. Fiske. 2001. "Stereotypes: Contents, Structures, Processes, anContext." In Intergroup Processes, edited by Rupert Brown and Samuel L. Gaertner, 22-44. Malden, MA: Blackwell. 
Pendleton, Wade C. 1996. Katutura, a Place Where We Stay: Life in a Post-Apartheid Township in Namibia. Athens: Ohio University Center for International Studies.

Ponelis, Fritz A. 1998. Standaardafrikaans en die Afrikaanse taalfamilie [Standard Afrikaans and the Afrikaans Language Family]. Stellenbosch: Universiteit van Stellenbosch.

Rampton, Ben. 1995. Crossing: Language and Ethnicity among Adolescents. New York: Longman.

Rickford, John. 1999. African American Vernacular English. Malden: Blackwell.

Robins, Steven L. 2008. From Revolution to Rights in South Africa. Social Movements, NGOs and Popular Politics after Apartheid. Pietermaritzburg: University of Kwazulu Natal Press.

Stokoe, Elizabeth. 2012. "Moving Forward with Membership Categorization Analysis: Methods for Systematic Analysis.” Discourse Studies 14: 277-303. doi:10.1177/14614456 12441534.

Tajfel, Henry. 1978. Differentiation between Social Groups: Studies in the Social Psychology of Intergroup Relations. London: Academic Press.

Van Dijk, Teun. 1993. Analyzing Racism through Discourse Analysis: Some Methodological Reflections. Amsterdam: University of Amsterdam.

Van Rooyen, J. W. F. 2000. Implementing Affirmative Action in Namibia. Windhoek: NID.

Verkuyten, Maykel. 2004. The Social Psychology of Ethnic Identity. London: Taylor \& Francis.

Whetherell, Margaret. 2010. "The Field of Identity Studies." In The Sage Handbook of Identities, edited by Margaret Whetherell and Chandra Talpade Mohanty, 3-26. London: Sage.

Zienkowski, Jan. 2011. "Discursive Pragmatics: A Platform for the Pragmatic Study of Discourse." In Discursive Pragmatics, edited by Jan Zienkowski, Jan-Ola Östman, and Jeff Verschueren, 1-13. Amsterdam: Benjamins.

GERALD STELL is Lecturer in the Department of Modern Languages and Linguistics at the University of the West Indies, St Augustine, and Research Fellow in the Department of Afrikaans at the University of Pretoria.

ADDRESS: School of Humanities, Faculty of Humanities and Education, The University of the West Indies, St. Augustine, Trinidad and Tobago. Email: Gerald. Stell@sta.uwi.edu

TOM FOX is Lecturer in the Department of Sociology at the University of Namibia. ADDRESS: Faculty of Humanities and Social Sciences, University of Namibia, Namibia. Email: tfox@unam.na 